\title{
Notes on the rediscovery of mosses Anomodon perlingulatus (Anomodontaceae) and Curvicladium kurzii (Neckeraceae) in Yunnan, China
}

\author{
Wen-Zhang Ma ${ }^{1,4}$, James R Shevock ${ }^{2}$, Johannes Enroth ${ }^{3}$ \\ ${ }^{1}$ Herbarium, Key Laboratory for Plant Diversity and Biogeography of East Asia, Kunming Institute of Botany, \\ Chinese Academy of Sciences, Kunming, Yunnan 650201, China \\ ${ }^{2}$ Department of Botany, California Academy of Sciences, 55 Music Concourse Dr., \\ Golden Gate Park, San Francisco, California, USA 94118 \\ ${ }^{3}$ Johannes Enroth, Department of Biosciences and Botanical Museum, P.O. Box 7 (Unioninkatu 44), \\ FI-00014 University of Helsinki, Finland \\ ${ }^{4}$ Author for correspondence: mawenzhang@mail.kib.ac.cn
}

\begin{abstract}
Anomodon perlingulatus Broth. ex P.C. Wu \& Y. Jia and Curvicladium kurzii (Kindberg) Enroth are reported as rheophytic mosses for the first time in China. They were so rarely collected that their habitat preferences remained unknown. The newly obtained specimens have expanded our understanding on their morphological variability and ecological preferences. After re-examining the type specimen held in $\mathrm{H}$, the large size of median cells in A. perlingulatus is confirmed to be a measurement error made in the original description. An updated description is provided. Both A. perlingulatus and C. kurzii can be categorized as facultative rheophytes because of the limited number of specimens collected so far. We anticipate that with a better understanding of potential habitats of both species, that more occurrences in the neighboring provinces are likely to be discovered.
\end{abstract}

\section{Rediscovery of Anomodon perlingulatus Broth. ex P.C. Wu \& Y. Jia}

Anomodon perlingulatus was first recognized by Brotherus (1907) from a single specimen collected by the Italian missionary Giuseppe Giraldi in 1899 . However, the name was a nomen nudum. A diagnostic description was prepared and published in 2000 by P.C. Wu and Y. Jia based on the type material in H (Wu and Jia 2000).

During the examination of a series of Anomodon species collected in Yunnan Province, China, the first author found a specimen collected from the Gao-Li-Gong Mountain region that appeared to be morphologically consistent with the description of A. perlingulatus, except for the size of the median cells. The identification of the Yunnan collection as A.perlingulatus was soon confirmed after a re-measurement of the lamina cells of the type specimen ( $H-B R$ 0159005) by the third author. According to our examination, the cell size in the middle of the lamina is $7-10 \mu \mathrm{m} \times 10-13 \mu \mathrm{m}$, rather than " $60-70 \mu \mathrm{m} \times 75-90 \mu \mathrm{m}$ " as recorded in the species description by Wu and Jia (2000). We believe this was probably a result of a transcription error. Unfortunately, subsequent publications have either copied (Wu and Jia 2002; Wu et al. 2002) or slightly modified (Xiong 2014) this error from the original species description. According to the scale bar from Xiong (2014), the size of cells in the 
middle portion of the lamina is calculated as 7.8-9.4 $\mu \mathrm{m} \times 8.4-11.7 \mu \mathrm{m}$ based on the illustration, which is very close to the cell size of both the type specimen and our Yunnan collections. A detailed description based on our newly collected material is here provided.

Anomodon perlingulatus Broth. ex P.-C. Wu \& Y. Jia Acta Phytotaxonomica Sinica 38: 260. f. 2. 2000. [Anomodontaceae]

Published Illustrations: Wu and Jia (2002: 188, Plate 76, Figs 1-10); Wu et al. (2002: 137, Plate 446, Figs 1-10); Xiong (2014: 278, Plate 317, Figs 10-16)

Plants light green to yellowish green, not glossy. Medium sized, stems creeping, $1.5-3.0 \mathrm{~cm}$ long, primary branch $3.0-5.5 \mathrm{~cm}$ long, secondary branches $0.8-3.5 \mathrm{~cm}$ long, irregularly branched proximally and pinnately branched towards the distal end of primary branch. Leaves moderately appressed on branches when dry, erect-spreading when moist. Central strand present, formed by a group of small cells without increase in cell wall thickness (Fig. 1G). Leaves relatively fragile, abruptly narrowed from the broadly ovate base, forming a lingulate-shaped distal portion with rounded apex, unistratose in cross-section. Leaves from primary and secondary branches similar, differ slightly in size. Stem leaves mostly broken without apices. Primary branch leaves: $2.2-2.6 \mathrm{~mm}$ long, $0.8-0.9 \mathrm{~mm}$ wide at base, and $0.18-0.22 \mathrm{~mm}$ wide at apex; secondary branch leaves, $2.0-2.3 \mathrm{~mm}$ long, $0.6-0.7 \mathrm{~mm}$ wide at base, $0.22-0.24 \mathrm{~mm}$ wide at apex; and for young secondary branch leaves, $1.3-1.5 \mathrm{~mm}$ long, $0.4-0.5 \mathrm{~mm}$ wide at base, $0.16-0.22 \mathrm{~mm}$ wide at apex. Costa strong, $66-75 \mu \mathrm{m}$ thick at base, occupying up to $95 \%$ of the leaf length, and ending about 12-16 cells below apex. In primary branch leaf, cells above costa irregular quadrate, 7-8 $\mu \mathrm{m} \times 9-10 \mu \mathrm{m}$, thin-walled, 3-6 tiny papillae per cell; cells in middle short rectangular to polygon shaped, $7-9 \mu \mathrm{m} \times 10-13 \mu \mathrm{m}$, thin-walled, multipapillose; cells in central basal irregularly long-rectangular, lighter in color, thick-walled, minutely porose, $8-12 \mu \mathrm{m} \times 28-48 \mu \mathrm{m}, 1-2$ papillae per cell, sometimes these elongated pale-colored cells present only on one side of leaf; costa cells strongly porose, 50-80 $\mu \mathrm{m}$ long. Cells from secondary branch leaves similar in size and shape. Sporophytes unknown. Fig. 1.
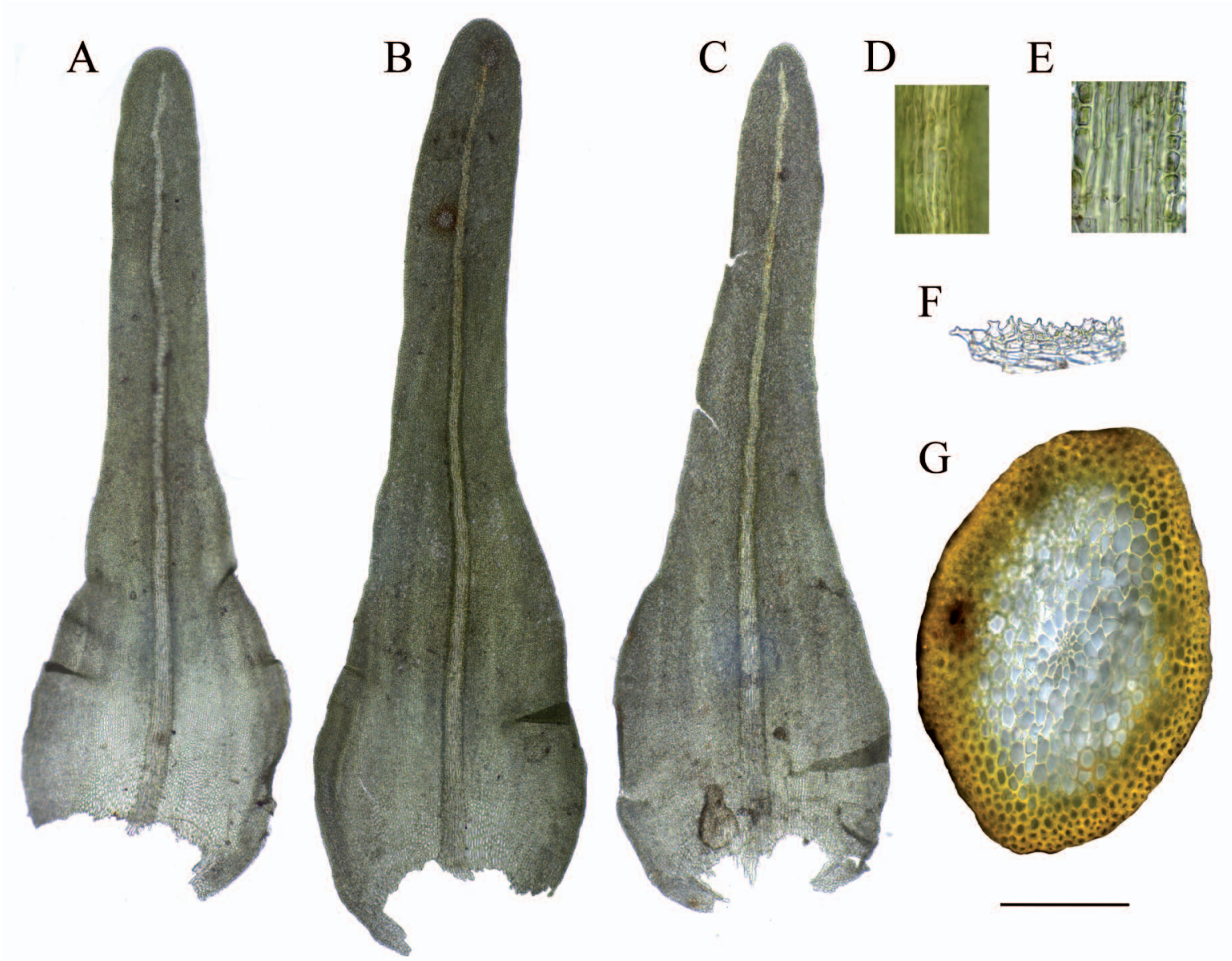

Fig. 1. Anomodon perlingulatus A, leaf from primary branch; B-C, leaves from secondary branch; $\mathbf{D}$, costa cells in the middle of leaf; E, costa cells in the bottom of leaf; F, marginal cells at decurrent leaf; G, cross section of stem. Scale bar $=50 \mu \mathrm{m}$. All images from Y.L. Yao 15-1033 (CAS). 
Recognition: Anomodon perlingulatus is smaller than A. minor (Hedw.) Lindb. and A. viticulosus (Hedw.) Hook. \& Taylor by leaf size, and the elongated and slim leaf apex is easily seen with the help of a hand-lens. Besides the unique leaf shape, the costa cells of $A$. perlingulatus are mostly smooth (Fig. 1D-E) with only inconspicuous prorations while several rounded papillae are more commonly seen in both A. minor and A. viticulosus.

Distribution and Ecology: The specimens of Anomodon perlingulatus were obtained from rocks along rivers where they are seasonally submerged. This is the first report of this species being found in a rheophytic environment, even though a more wide-spread species, A. viticulosus in western Yunnan always occupies similar habitats. From our field experience, A. perlingulatus often occupies the same niche with other more commonly collected members of the genus, such as A. viticulosus and A. minor, a rather common phenomenon where several Anomodon species tend to grow in mixed populations (Granzow-de la Cerda 1997).

Mao and Zhang (2011) reported Anomodon perlingulatus from the Langcangjiang (Headwater of Mekong River) Valley in northwest Yunnan Province. However, after examining the duplicates at CAS the specimens are actually A. viticulosus. Xiong (2014) cited several specimens collected in neighboring Guizhou Province, however, there is no habitat information. Unfortunately, those specimens have not been available to us to confirm their identity, even though we feel quite confident of its occurrence based on the illustration.

Many obligate rheophytes such as Handeliobryum sikkimense (Paris) Ochyra (Ochyra and Shevock 2012), Sciaromiopsis sinensis Broth., Schistidium riparium H.H. Blom, Shevock, D.G. Long \& Ochyra (Blom et al. 2011), and several species of Neckeropsis (Enroth 1999) have a thickened leaf border, as an adaptation to fast flowing water (Vitt and Glime 1984). However, A. perlingulatus lacks this structure, just like several other rheophytic bryophytes found in the same habitats such as Cyptodontopsis leveillei (Thér.) P. C. Rao \& Enroth (Ma et al. 2014), Hydrocryphaea wardii Dixon (Shevock et al. 2006), and Yunnanobryon rhyacophilum Shevock, Ochyra, S. He \& D.G. Long (Shevock et al. 2011).

Many leaves from the proximal part of the primary branch were broken, leaving strong costae behind. These badly eroded leaves were likely a result of silt abrasion in swift-running water. This suggests A. perlingulatus may not be specifically adapted to this aquatic environment, or else this species may have evolved certain mechanisms to combat frequent physical disturbances. Since Anomodon species rarely produce capsules in China, the fragments scoured away from mature leaves by water could function as asexual propagules, a phenomenon also observed in the rheophilous species Neckeropsis moutieri (Broth. \& Paris) M. Fleisch. (He and Zhang 2007). The sporophyte of A. perlingulatus remains unknown, and the species is highly likely to be diocious, so the fragile leaf border may serve as an efficient means of vegetative dispersal.

Due to the under-collection of this species, its specific ecological requirements in rheophytic habitats are difficult to elaborate. Also, because there is no experimental evidence to verify the function of broken margins of old leaves in vegetative dispersal, it is prudent to categorize A.perlingulatus as a facultative rheophyte. Nonetheless, rocky and woody substrates along riparian sites that experience irregular submersion are still the most likely habitats for $A$. perlingulatus.

Specimens examined: Honghe, Ge-Jiu City, Man-Hao Zhen, Lv-Shui-He tropical rain forest scenic spot, alt. $470 \mathrm{~m}$, on granite rock at river bank, seasonally submerged, Y. L. Yao 15-1033, 3 Oct 2015 (CAS, KUN); Nujiang. Fu-Gong Co., Pi-He Xiang, alt. $1080 \mathrm{~m}$, on shady wall of large marble boulder by river, D. G. Long 35187, 23 Aug 2005 (CAS, E, KUN); Zi-Li-Jia Xiang, east side of Nujiang, alt. 1130 m, on rock of river bank seasonally submerged, W. Z. Ma 13-5192, 22 Sep 2013 (CAS, H, KUN).

Notes: In Brotherus (1907), the species epithet was printed as "perlinguatus", but Brotherus wrote "perlingulatus" on the specimen label (Fig. 2), which consists of the Latin prefix "per-" and "lingulatus", indicating the plants are characterized by "tongue-shaped" leaves throughout. The Latin "linguatus" means "eloquent, gifted in speech", which apparently makes much less sense especially when the leaves are indeed tongue-shaped.

It is interesting that both the correct and misspelled species epithet appear in literature. Initially, Brotherus had it right on the type specimen label but later it appeared with a typographical error in the protologue (Brotherus 1907), and over a century later, Wu and Jia (2000) corrected the error but again missing the second "1" in Moss Flora of China Volume 6 (Wu et al. 2002). We brought this issue to the attention of the herbarium in Missouri Botanical Garden (MO) and Anomodon perlingulatus has since been amended on TROPICOS (http://www.tropicos.org/). The label of the type material states "China interior, provincia Schen-si septentr., in monte Kan-y-san (caten. Lao-y-san), 18 Jun. 1899, legit Rev. Jos. Giraldi". It is important to note that the number 1272 on the label is not Giraldi's collection number but a herbarium number, because the label is titled as "Herbarium E. Levier". 
HOLOTYPE

Anomodon perlingulatus Broth. ex P.-C. Wu \& Y. Jia Acta Phytotax. Sinica. 38: 260. 2000.

(annotation by J. Enroth 2014)

Herb. V. F. Brotherus (H.BR) no.

0159005

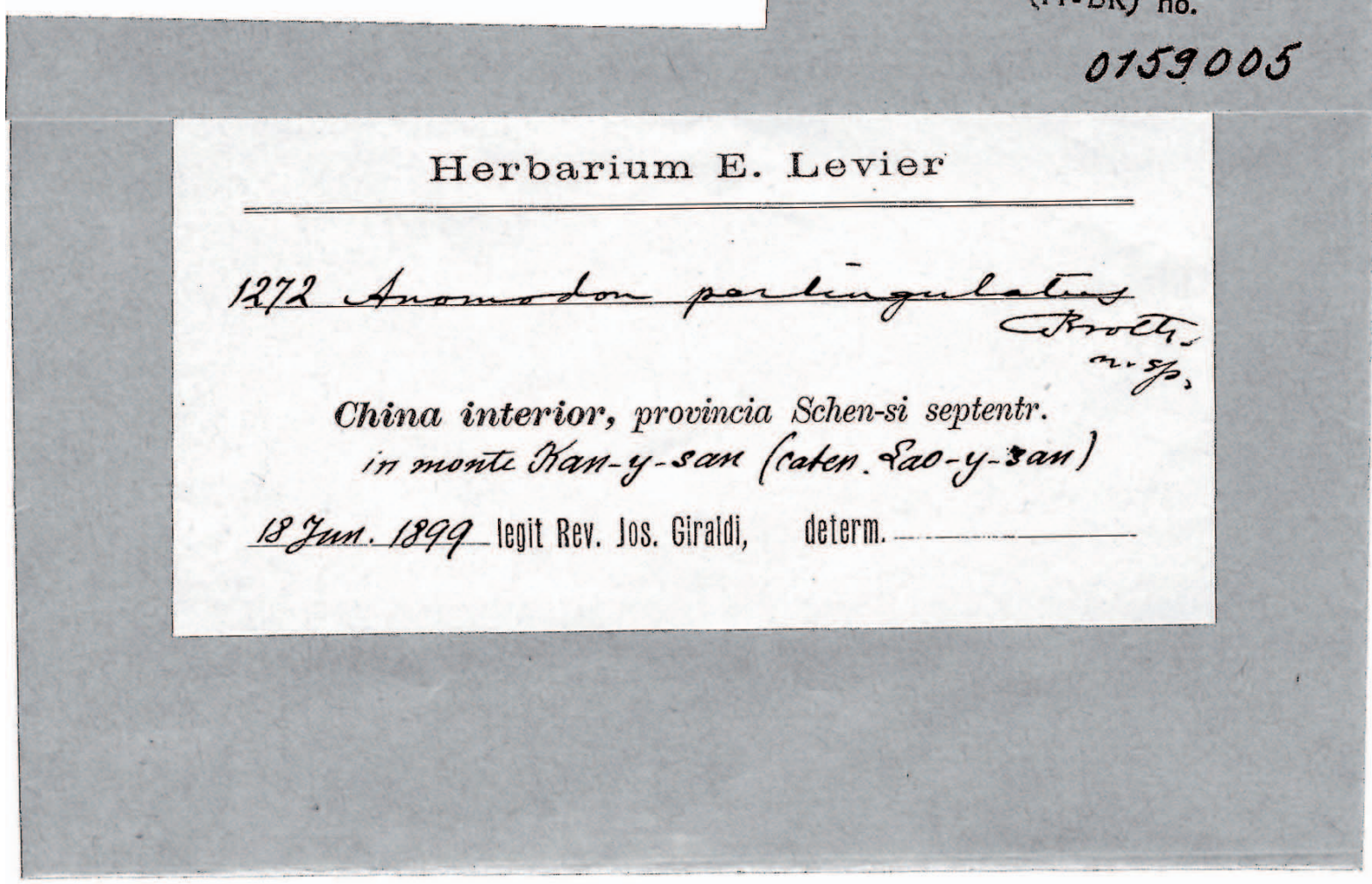

Fig. 2. Label of the holotype specimen of Anomodon perlingulatus.

\section{Redicovery of Curvicladium kurziii (Kindberg) Enroth}

Curvicladium is a Himalayan monospecific genus, established by Enroth (1993) based on species previously placed in the genera Thamnobryum (also as Thamnium, which is a later homonym) and Pinnatella. The generic features of Curvicladium were discussed in great detail by Enroth (1993) and the most striking features, especially relative to Pinnatella, include: often arcuate stems and branches, coarse teeth formed by multiple cells in the leaf apex, a long $(8-11 \mathrm{~mm})$ and twisted seta, and post-fertilization growth of perichaetial leaves. Olsson et al. (2010) showed that Curvicladium belongs in an essentially Asian and morphologically heterogenous Pinnatella-clade in the Neckeraceae, but its detailed relationships remain unresolved.

Previously known in China from a single specimen collected in Yunnan over 50 years ago, Curvicladium kurzii is now reported from several National Nature Reserves in the province, and with one occurrence documented in a stream channel. The historical voucher specimen was collected by "D. of F.Y.U." (Enroth 1993), which we deciphered as an abbreviation for "Department of Forestry, Yunnan University". Additional material of this species might be found among undetermined specimens in the herbarium at Yunnan University (YUKU). The collecting site of this specimen was cited differently as "Chen-Kang County" in Enroth (1993) and "ZengKong Co." in Wu (2011), however, there is no county spelling like either of the above in Yunnan today. We assume those spellings were originated from Postal Romanization, where "Zhen-Kang" County in Lin-Cang City, southwest Yunnan, turned out to be the best match.

As we were about to "announce" the finding of this rare species from Yong-De-Da-Xue-Shan National Nature Reserve in Yong-De County, the first author realized there was an interesting background regarding the name of this county. There was no county named Yong-De before it separated from a part of the previous Zhen-Kang County in 1964, and all recorded plant specimens labeled with "Chen-Kang" before that year were actually collected in what is now Yong-De County (Liu 2006). This statement is further confirmed by "Snow mountain, 
$2300 \mathrm{~m}$, on bark, 18. IV. 1964" from the specimen label (Enroth 1993), namely referring to the Da-Xue-Shan (which means giant snow mountain) in Yong-De County. Thus our C. kurzii collections were not a second location but just a rediscovery of the historical record.

Two more populations of this largely Himalayan genus were found in different counties in Yunnan during later bryological expeditions, and a search of herbarium collections at CAS and KUN also yielded additional locations (see specimens examined).

Curvicladium kurzii (Kindberg) Enroth Annales Botanici Fennici 30: 110. 1993.

[Neckeraceae]

Published Illustrations: Wu (2011: 370, Plate 387, Figs. 1-9); Gangulee (1976: 1442 as Pinnatella kurzii).

Specimens examined: Honghe, Jin-Ping Co., Zhe-Mi Xiang, Liang-Zi Village, Xi-Long Mountain, Fen-ShuiLing National Nature Reserve, on trunk of huge tree in old-growth broad-leaved forest, alt. $2240 \mathrm{~m}$, W.Z. Ma 15-7037, 30 Sep 2015 (CAS, KUN); Baoshan, Teng-Chong Co., near Lin-Jia-Pu Forestry station, on trunk in broad-leaved evergreen forest, alt. $2439 \mathrm{~m}$, W. Z. Ma 14-5518, 19 Mar 2014 (KUN); same general vicinity, W. Z. Ma 14-5535 (KUN); along trial to Nan-Zhai-Gong-Fang Pass, Gao-Li-Gong-Shan National Nature Reserve, on metamorphic rock in stream water splashing zone, alt. $2513 \mathrm{~m}, \mathrm{~W}$. Z. Ma et Shevock 14-5766, 12 Jul 2014 (CAS, H, KUN); Dehong, Ying-Jiang Co., Meng-Long Xiang, Sa-Shui River, on granite rock by stream, alt. 1940 m, W. Z. Ma 15-6298, 4 May 2015 (CAS, KUN); Lincang, Yong-De Co., Yong-De National Nature Reserve near wildlife monitoring cabin, alt. 2274 m, W. Z. Ma et Shevock 14-5576, 29 Jul 2014 (CAS, KUN); same general vicinity, on base of hardwood trunk in filtered light, Shevock et W. Z. Ma 45244, 30 Jul 2014 (CAS, KUN, H, MO); same general vicinity, on hardwood trunk in filtered light, Shevock et W. Z. Ma 45250, 30 Jul 2014 (CAS, H, KUN). Fig. 3.

Recognition: Curvicladium kurzii shares many morphological similarities with Pinnatella, such as the general branching pattern and the overall leaf shape, as well as the rectangular intra-marginal cells near the alar region. However, C. kurzii is easily distinguished from the latter by having arcuate branches that sometimes grow up to $10 \mathrm{~cm}$ long, as well as capsules borne on a long seta compared with exserted capsules in Pinnatella.

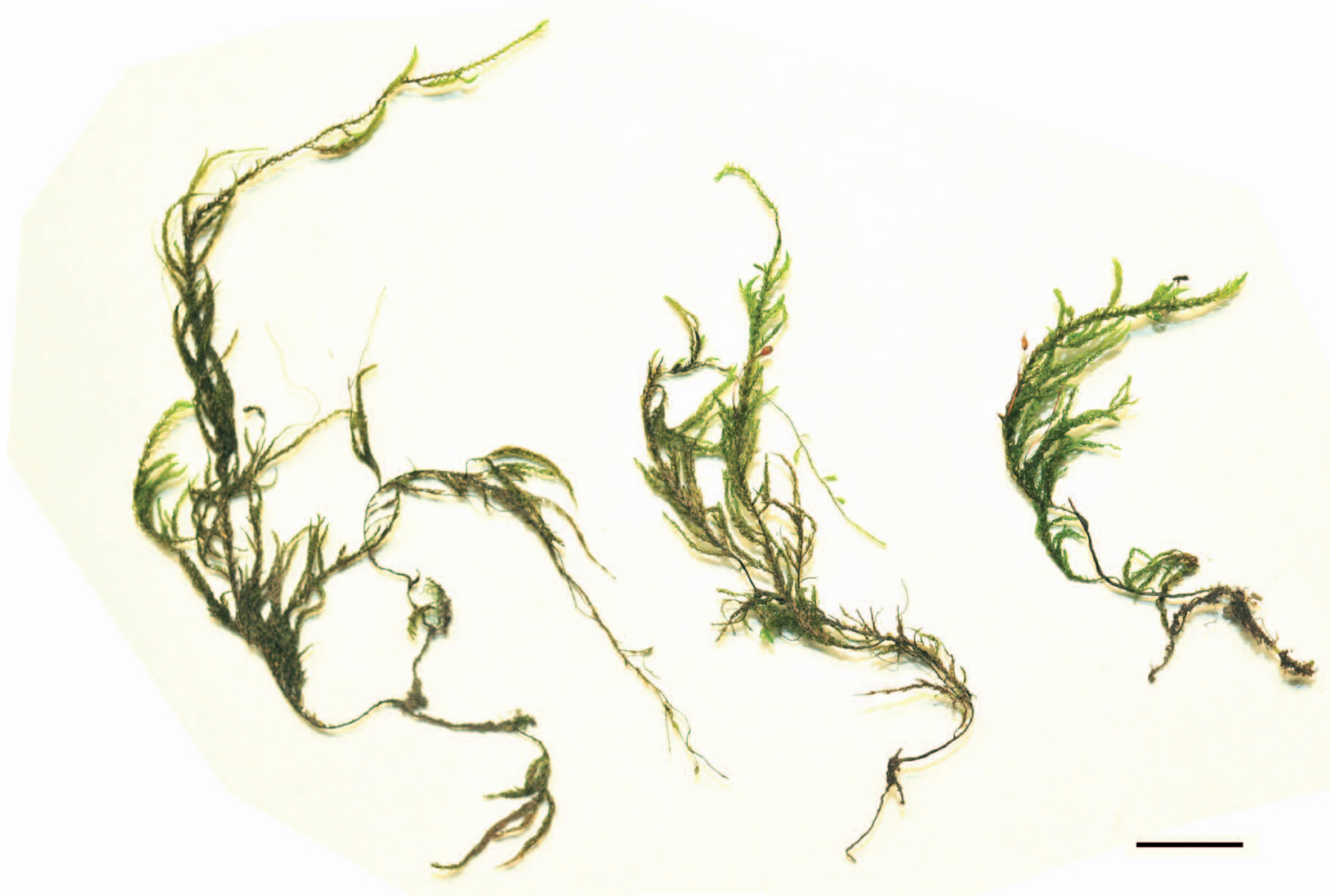

Fig. 3. Plants of Curvicladium kurzii with capsules. Scale bar $=1 \mathrm{~cm}$. Image from W.Z. Ma 15-6298 (CAS). 
Distribution and ecology: The elongated stem would allow C. kurzii some flexibility in a water-flowing environment. Similar to the long seta of Handeliobryum sikkimense (Ochyra and Shevock 2012), the long seta of $C$. kurzii could be viewed as a special adaptation in the periodically submerged habitat. In addition, the post-fertilization growth of perichaetial leaves observed by Enroth (1993), may be a special protective mechanism that reduces the mechanical impact from running water to the maturing capsules. Even though only one specimen so far was collected in rheophytic habitats, the above-mentioned morphological traits indicate that C. kurzii can also be a facultative rheophyte.

Although rarely collected, Curvicladium kurzii is not suggested to be viewed as a dispersal-limited species which deserves any further conservation attention based on the current distribution data. Apart from the previously cited location in Yong-De County, geographically speaking, our newly collected populations of C. kurzii were scattered in four different southern counties in Yunnan. The distance between Ying-Jiang $\left(24^{\circ} 51^{\prime} 17^{\prime \prime} \mathrm{N}, 9^{\circ} 53^{\prime} 43^{\prime \prime} \mathrm{E}\right)$ and Jin-Ping $\left(22^{\circ} 39^{\prime} 49^{\prime \prime} \mathrm{N}, 102^{\circ} 47^{\prime} 56^{\prime \prime} \mathrm{E}\right)$, the two most distant sites, is roughly over $550 \mathrm{~km}$, covering $2 / 3$ the width of the province. This shows C. kurzii has the capability to colonize a wide range of its potential habitats in Yunnan. Actually, C. kurzii is quite widespread in southwest Asia as it had been reported from India, Nepal and Thailand (Enroth 1993). We believe this species is largely undercollected rather than very rare.

Because all our recent collections were obtained from National Nature Reserves, the presence of this species is somehow associated with forests preserved in good condition. Unlike most other members of Neckeraceae, C. kurzii appears to be fairly intolerant to fluctuation in light and water supply, and field data suggests it is often associated with a forest environment with deep shade and high atmospheric humidity. This probably implies that $C$. kurzii is very sensitive to anthropogenic disturbances that unpredictably change the light regime. In searching for more populations of $C$. kurzii, future bryological expeditions should pay special attention to montane forests between elevation $1900 \mathrm{~m}$ and $2600 \mathrm{~m}$ at shaded, humid and even perhaps rheophytic sites in Sichuan, Taiwan, Yunnan and Xizang. There may be an interesting distribution pattern of C. kurzii associated with primary forests should more new occurrences be discovered.

\section{Acknowledgments}

Funds for field expeditions in 2015 were provided by the National Geographic Society (9697-15) and is much appreciated. We thank the Forestry department of Yunnan Provincial Government for permitting us to do field work in the National Nature Reserves, and the staff from Yong-De-Da-Xue-Shan National Nature Reserve who provided assistance during a field trip in 2014. Microscopic images were created using the facilities from the John T. Howell Botanical Lab., with credit given to the Botany Department, California Academy of Sciences. Two anonymous reviewers provided comments that enhanced the final version.

\section{References}

Blom HH, Shevock JR, Long DG and Ochyra R (2011) Two new rheophytic Schistidium (Grimmiaceae) from China. Journal of Bryology 33: 179-188 http://dx.doi.org/10.1179/1743282011Y.0000000020

Brotherus VF (1907) Fabroniaceae-Leskeaceae. Pp. 899-1008. in Engler A and Prantl K (eds.) Die Natürlichen Pfanzenfamilien. I (3) (W. Engelmann: Leipzig)

Enroth J (1993) Notes on the Neckeraceae (Musci), 18. Description of Curvicladium, a new genus from southern and southeastern Asia. Annales Botanici Fennici 30: 109-117

Enroth J (1999) A review of the rheophytic Neckeraceae (Musci). Haussknechtia Beiheft 9: 121-127

Gangulee HC (1976) Mosses of Eastern India and Adjacent Regions, Fascicle 5, Isobryales. (Published by the author: Calcutta.)

Granzow-de la Cerda I (1997) Revision and phylogeny of Anomodon and Herpetineuron. Contributions University Michigan Herbarium 21: 205-275

He S, Zhang L (2007) Neckeropsis moutieri (Neckeraceae), a Southeast Asia species new to China. Journal of Tropical and Subtropical Botany 15: 545-548

Liu ED (2006) Floristic study on vascular plants in Yongde Daxueshan. (Unpublished Ph.D Thesis: Kunming Institute of Botany, Chinese Academy of Sciences)

Ma WZ, Shevock JR, Enroth J (2014) Rediscovery of the monospecific genus Cyptodontopsis (Cryphaeaceae) in China: a species restricted to flood plain habitats. Acta Bryolichenologica Asiatica 5: 141-149

Mao LH, Zhang L (2011) Mosses of the Langcangjiang River valley (Yunlog-Deqin Section), Yunnan China. Journal of Fairylake Botanical Garden 10: 11-20

Noguchi A (ed.) (1989) Illustrated Moss Flora of Japan, Part 3. Hattori Botanical Laboratory. Nichinan-Shi 
Ochyra R., Shevock JR (2012) A fruiting plant of Handeliobryum sikkimense (Bryopsida, Thamnobryaceae) from Yunnan, China. Nova Hedwigia 94: 307-321 http://dx.doi.org/10.1127/0029-5035/2012/0021

Olsson S, Buchbender V, Enroth J, Hedenäs L, Huttunen S, Quandt D (2010) Phylogenetic relationships in the "Pinnatella" clade of the moss family Neckeraceae. Organisms Diversity \& Evolution 10: 107-122. http:// dx.doi.org/10.1007/s13127-010-0017-z

Shevock JR, Ochyra R, Buck WR (2006) Observations on the ecology and distribution of Hydrocryphaea wardii, a southeast Asian monospecific genus, reported new for China from Yunnan Province, Journal of the Hattori Botanical Laboratory 100: 407-418

Shevock JR, Ochyra R, He S, Long DG (2011) Yunnanobryon, a new rheophytic moss genus from southwest China. Bryologist 114: 194-203 http://dx.doi.org/10.1639/0007-2745-114.1.194

Vitt DH, Glime JM (1984) The structural adaptations of aquatic Musci. Lindbergia 10: 95-110

Wu PC, Jia Y (2000) A revision of Chinese Thuidiaceae (s.l., Musci). Acta Phytotaxonomica Sincica, 38: 256-265

Wu PC, Jia Y (2002). Anomotontaceae. In Wu PC (ed.) Flora Bryophytarum Sinicorum. Volume 6 HookerialesHypnobryales. Chinese Academy of Sciences, Science Press, Beijing [in Chinese]

Wu PC, Jia Y, Wang MZ (2002) Anomodontaceae. Pp. 131-149. in: Wu PC and Crosby MR (eds-in-chief), He S (ed.) Moss Flora of China, English Version, Vol. 6. Hookeriaceae-Thuidiaceae. (Science Press: Beijing and New York; Missouri Botanical Garden Press: St. Louis)

Wu PC (2011) Thamnobryaceae. Pp. 369-384. in Wu, PC and MR Crosby (eds-in-chief), S He (ed.). Moss Flora of China, English Version, Vol. 5. Erpodiaceae-Climaciaceae. Science Press: Beijing and New York; Missouri Botanical Garden Press: St. Louis

Xiong YX (ed.) (2014) Moss Flora of Guizhou Province (Vol. 2). (Guizhou Science and Technology Publishing House: Guiyang)

Manuscript received 3 February 2016, accepted 30 March 2016 